\title{
Effect of magnetite nanoparticles on dye absorption properties of magnetite@carbon composites
}

\author{
YUNFANG LIU ${ }^{1, *}$, YANGYANG LI ${ }^{1}$, XIN ZHAO ${ }^{1}$, WEIDONG CHI ${ }^{1}$, QIGU HUANG ${ }^{1}$, \\ CHANGYUAN YU ${ }^{2}$ and YONG XIANG \\ ${ }^{1}$ Key Laboratory of Carbon Fibers and Functional Polymers of Ministry of Education, Beijing University of Chemical \\ Technology, Beijing 100029, People's Republic of China \\ ${ }^{2}$ College of Life Science and Technology, Beijing University of Chemical Technology, Beijing 100029 , \\ People's Republic of China \\ ${ }^{3}$ Sinopuri Environment Engineering Science and Technology (Shanghai) Co. Ltd, Shanghai 200090, \\ People's Republic of China
}

MS received 8 December 2015; accepted 7 July 2016

\begin{abstract}
Magnetite@carbon $\left(\mathrm{Fe}_{3} \mathrm{O}_{4} @ \mathrm{C}\right)$ composites were prepared using three kinds of $\mathrm{Fe}_{3} \mathrm{O}_{4}$ nanoparticles (NPs). All the $\mathrm{Fe}_{3} \mathrm{O}_{4} @ \mathrm{C}$ composites could be easily separated from water by an external magnet. $\mathrm{The}^{\mathrm{Fe}} \mathrm{O}_{4} \mathrm{NPs}$ synthesized by a microreactor system have the smallest size and narrowest size distribution among the three kinds of $\mathrm{Fe}_{3} \mathrm{O}_{4}$ NPs. The saturated capacity of the $\mathrm{Fe}_{3} \mathrm{O}_{4} @ \mathrm{C}$ composite originating from microreactor-prepared $\mathrm{Fe}_{3} \mathrm{O}_{4}$ NPs to absorb Rhodamine $\mathrm{B}$ at $20^{\circ} \mathrm{C}$ exceeds $135 \mathrm{mg} \mathrm{g}^{-1}$, which is 1.35 times as much as the value of the $\mathrm{Fe}_{3} \mathrm{O}_{4} @ \mathrm{C}$ composite originating from traditional $\mathrm{Fe}_{3} \mathrm{O}_{4} \mathrm{NPs}$. This value for the $\mathrm{Fe}_{3} \mathrm{O}_{4} @ \mathrm{C}$ composite using commercial $\mathrm{Fe}_{3} \mathrm{O}_{4}$ NPs as core is only $76 \mathrm{mg} \mathrm{g}^{-1}$. The $\mathrm{Fe}_{3} \mathrm{O}_{4} @ \mathrm{C}$ composite using microreactor-prepared $\mathrm{Fe}_{3} \mathrm{O}_{4} \mathrm{NPs}$ also has good retrievability and reusability.
\end{abstract}

Keywords. Magnetite; carbon composite; microreactor; absorption property.

\section{Introduction}

Treatment technologies for dye-containing wastewater have become more and more important, especially for paper making, plastics, printing and textiles, due to its bad biodegradability. Adsorption is an effective and attractive process. Many adsorbents have been used, such as metal oxides and carbon materials [1-4]. Recently, magnetite@carbon $\left(\mathrm{Fe}_{3} \mathrm{O}_{4} @ \mathrm{C}\right)$ composites have also attracted great attention as adsorbents due to their excellent absorption ability and high separation efficiency. Many methods were used for $\mathrm{Fe}_{3} \mathrm{O}_{4} @ \mathrm{C}$ composites with different $\mathrm{Fe}_{3} \mathrm{O}_{4}$ cores [5-11]. $\mathrm{Fe}_{3} \mathrm{O}_{4}$ cores are one of the key factors for excellent property of $\mathrm{Fe}_{3} \mathrm{O}_{4} @ \mathrm{C}$ composite, whose structure and property have great impact on the properties of $\mathrm{Fe}_{3} \mathrm{O}_{4} @ \mathrm{C}$ composites. Many methods have been developed for preparation of $\mathrm{Fe}_{3} \mathrm{O}_{4}$ nanoparticles (NPs), such as hydrothermal or solvothermal method, sol-gel method, coprecipitation method, reflux method and ball milling method [12-18]. Compared with other methods, the coprecipitation method (traditional adding method) has some advantages due to its simplicity, high applicability and high product purity [18]. But $\mathrm{Fe}_{3} \mathrm{O}_{4}$ NPs prepared by this method still suffer some shortcomings, such as relatively large particle size, wide size distribution and severe aggregation [18]. These problems will obviously impair the properties of $\mathrm{Fe}_{3} \mathrm{O}_{4} @ \mathrm{C}$ composites.

*Author for correspondence (liuyunfang@ mail.buct.edu.cn)
Microreactors as a small reaction system could provide efficient repeatability and highly selective production of NPs due to their unique geometric features (microscale, large specific surface area, small volume and unique fluid behaviour) [19-22]. Therefore, NPs with certain size and uniform size distribution could be obtained more easily. In this work, we synthesized $\mathrm{Fe}_{3} \mathrm{O}_{4}$ NPs using a microreactor system for $\mathrm{Fe}_{3} \mathrm{O}_{4} @ \mathrm{C}$ composite. For comparison, $\mathrm{Fe}_{3} \mathrm{O}_{4}$ NPs from the traditional adding method and commercial samples were also used. The structure and magnetic and dye absorption properties of $\mathrm{Fe}_{3} \mathrm{O}_{4} @ \mathrm{C}$ composites were investigated.

\section{Experimental}

\subsection{Materials}

Ferrous sulphate $\left(\mathrm{FeSO}_{4} \cdot 7 \mathrm{H}_{2} \mathrm{O}\right)$, ferric trichloride $\left(\mathrm{FeCl}_{3}\right.$. $6 \mathrm{H}_{2} \mathrm{O}$ ) and commercial $\mathrm{Fe}_{3} \mathrm{O}_{4} \mathrm{NPs}$ were bought from Beijing Modern Oriental Fine Chemicals Co., Ltd. Soluble starch $\left(\left(\mathrm{C}_{6} \mathrm{H}_{10} \mathrm{O}_{5}\right)_{n}\right)$ and $\mathrm{NaOH}$ were obtained from Beijing Yili Fine Chemicals Co., Ltd. Rhodamine B (RhB) was purchased from Tianjin Guangfu Fine Chemical Research Institute. In our study, all chemicals used were of analytical grade.

\subsection{Synthesis of $\mathrm{Fe}_{3} \mathrm{O}_{4} \mathrm{NPs}$ and $\mathrm{Fe}_{3} \mathrm{O}_{4} @ \mathrm{C}$ composites}

$\mathrm{Fe}_{3} \mathrm{O}_{4}$ NPs were prepared by two methods (microfluid synthesis and traditional coprecipitation synthesis). For the 
former, $120 \mathrm{ml}$ of aqueous solution $\mathrm{A}\left(1.151 \mathrm{~g}\right.$ of $\mathrm{FeCl}_{3}$. $6 \mathrm{H}_{2} \mathrm{O}$ and $0.778 \mathrm{~g}$ of $\mathrm{FeSO}_{4} \cdot 7 \mathrm{H}_{2} \mathrm{O}$ ) and $120 \mathrm{ml}$ of aqueous solution $\mathrm{B}(0.9 \mathrm{~g}$ of $\mathrm{NaOH})$ were synchronously pumped at a constant flow rate $(20 \mathrm{ml} \mathrm{min}-1)$ into two inlets of a micromixer connected with a PTFE capillary tube (ID: $0.5 \mathrm{~mm}$, length: $1 \mathrm{~m}$ ) at the outlet (labelled as $\mathrm{MR}-\mathrm{Fe}_{3} \mathrm{O}_{4}$ ). For the latter, $120 \mathrm{ml}$ of solution A was dropped into solution $\mathrm{B}(120 \mathrm{ml})$ with mechanical agitation and ultrasound (labelled as TA- $\mathrm{Fe}_{3} \mathrm{O}_{4}$ ). The commercial $\mathrm{Fe}_{3} \mathrm{O}_{4}$ sample was labelled as $\mathrm{C}-\mathrm{Fe}_{3} \mathrm{O}_{4}$.

To prepare $\mathrm{Fe}_{3} \mathrm{O}_{4} @ \mathrm{C}$ composites, $\mathrm{Fe}_{3} \mathrm{O}_{4}$ NPs $(0.65 \mathrm{~g})$, soluble starch $(3 \mathrm{~g})$ and $\mathrm{H}_{2} \mathrm{O}(55 \mathrm{ml})$ were mixed and transferred to a Teflon-sealed autoclave and kept at $180^{\circ} \mathrm{C}$ for $20 \mathrm{~h}$. The solid product was magnetically separated, and repeatedly rinsed with water and ethanol several times. After that, the $\mathrm{Fe}_{3} \mathrm{O}_{4} @ \mathrm{C}$ composites were dried overnight at $65^{\circ} \mathrm{C}$ (correspondingly labelled as MR- $\mathrm{Fe}_{3} \mathrm{O}_{4} @ \mathrm{C}, \mathrm{TA}-\mathrm{Fe}_{3} \mathrm{O}_{4} @ \mathrm{C}$ and $\left.\mathrm{C}-\mathrm{Fe}_{3} \mathrm{O}_{4} @ \mathrm{C}\right)$.

\subsection{Adsorption characterization}

$\mathrm{RhB}$ was used as a model compound to evaluate the adsorption property of the $\mathrm{Fe}_{3} \mathrm{O}_{4} @ \mathrm{C}$ composites. Each batch experiment was performed as follows: firstly, RhB solution $\left(1 \mathrm{~g} \mathrm{l}^{-1}, 100 \mathrm{ml}\right)$ was prepared and its $\mathrm{pH}$ value was adjusted to be in the range of 3-11 using $\mathrm{HCl}$ or $\mathrm{NaOH}$ solutions; secondly, the absorbing material $(0.1 \mathrm{~g})$ was added into this solution with agitation for a certain time; then, the magnetic materials were separated from the solution using a magnet, and the RhB concentration was measured using a UV-vis spectrophotometer at the wavelength of $554 \mathrm{~nm}$. The adsorption capacity at different times $\left(q_{t}\right)$ was calculated using the following equation:

$$
q_{t}=\left(C_{0}-C_{t}\right) / C_{\mathrm{a}}
$$

In this equation, $C_{0}$ is the initial concentration of $\mathrm{RhB}, C_{t}$ is the concentration of $\mathrm{RhB}$ at different absorption times and $C_{\mathrm{a}}$ is the concentration of absorption material.

To evaluate the reusability of $\mathrm{Fe}_{3} \mathrm{O}_{4} @ \mathrm{C}$ composite, regeneration experiment was performed as follows: (1) after saturated adsorption, $\mathrm{Fe}_{3} \mathrm{O}_{4} @ \mathrm{C}$ composite was separated from water and simply washed with deionized water several times; (2) after drying, the recovered $\mathrm{Fe}_{3} \mathrm{O}_{4} @ \mathrm{C}$ composite was used for the next adsorption experiment.

\subsection{Recovery experiment}

The recovery experiment was performed as follows: (1) $\mathrm{Fe}_{3} \mathrm{O}_{4} @$ carbon composite $(50 \mathrm{mg})$ was added into deionized water (100 ml) and dispersed by agitation; (2) $\mathrm{Fe}_{3} \mathrm{O}_{4} @$ carbon composite was separated from water by an external magnet and kept in an oven to dry at $110^{\circ} \mathrm{C}$ for 12 h; (3) The dried sample was weighed and the recovery $\eta$ was calculated according to the following equation:

$$
\eta=\left(m / m_{0}\right) \times 100 \% .
$$

In this equation, $m_{0}$ is the initial mass of $\mathrm{Fe}_{3} \mathrm{O}_{4} @$ carbon composite and $m$ is the mass of the recovered $\mathrm{Fe}_{3} \mathrm{O}_{4} @$ carbon composite.

\subsection{Structural characterization}

The microstructures and crystal structures of the samples were characterized by transmission electron microscopy (TEM, FEI, Tecnai-G2) and X-ray diffraction (XRD, Rigaku, $\mathrm{D} / \mathrm{Max} 2500 \mathrm{VB} 2+/ \mathrm{PC}, \mathrm{CuK} \alpha, \mathrm{K} \alpha=0.15418 \mathrm{~nm}, 40 \mathrm{kV}$, $200 \mathrm{~mA}$ ), respectively. The surface and magnetic properties of the samples were analysed using an infrared spectrum analyzer (IR, TNZ1-5700) and a vibrating sample magnetometer (EG \& GVSM Model 155), respectively. The surface states of the materials were characterized by X-ray photoelectron spectra (XPS, Thermo Fisher Scientific, Escalab250).

\section{Results and discussion}

The TEM images of $\mathrm{Fe}_{3} \mathrm{O}_{4}$ samples and their statistical size-distribution histograms are showed in figure 1. It can be observed that $\mathrm{C}-\mathrm{Fe}_{3} \mathrm{O}_{4}$ NPs and TA- $\mathrm{Fe}_{3} \mathrm{O}_{4}$ NPs suffer more serious aggregation than $\mathrm{MR}-\mathrm{Fe}_{3} \mathrm{O}_{4} \mathrm{NPs}$. The average particle sizes of $\mathrm{C}-\mathrm{Fe}_{3} \mathrm{O}_{4}, \mathrm{TA}-\mathrm{Fe}_{3} \mathrm{O}_{4}$ and $\mathrm{MR}-\mathrm{Fe}_{3} \mathrm{O}_{4}$ are about 28.2, 11.7 and $9.7 \mathrm{~nm}$, respectively. $\mathrm{MR}-\mathrm{Fe}_{3} \mathrm{O}_{4} \mathrm{NPs}$ have the smallest size and narrowest size distribution among them. The nucleation and growth of $\mathrm{MR}-\mathrm{Fe}_{3} \mathrm{O}_{4} \mathrm{NPs}$ could be divided and controlled well because of the tiny channel and strong mass transmittability of the microreactor $[19,20]$. As a result, $\mathrm{Fe}_{3} \mathrm{O}_{4} \mathrm{NPs}$ with narrow size distribution and good dispersion were obtained. The TEM images of $\mathrm{Fe}_{3} \mathrm{O}_{4} @ \mathrm{C}$ composites (figure 2) clearly show the carbon encapsulation of $\mathrm{Fe}_{3} \mathrm{O}_{4}$ NPs.

Figure 3 shows the XRD patterns of $\mathrm{Fe}_{3} \mathrm{O}_{4}$ and $\mathrm{Fe}_{3} \mathrm{O}_{4} @ \mathrm{C}$ composites. All $\mathrm{Fe}_{3} \mathrm{O}_{4}$ samples have the standard diffraction peaks of $\mathrm{Fe}_{3} \mathrm{O}_{4}$ material with a cubic spinel structure of $\mathrm{Fe}_{3} \mathrm{O}_{4}$ (JCPDS No. 19-0629). In these patterns, the distinct peaks at $30.2,35.6,43.2,53.7,57.2$ and $62.8^{\circ}$ of $2 \theta$ are assigned to crystal planes (220), (311), (400), (422), (511) and (440), respectively. The lattice spacing value of about $0.253 \mathrm{~nm}$ for (311) crystal plane is in accordance with the JCPDS database (JCPDS No. 19-0629). According to the Scherrer equation using (311) diffraction peak, the sizes of $\mathrm{C}-\mathrm{Fe}_{3} \mathrm{O}_{4}, \mathrm{TA}-\mathrm{Fe}_{3} \mathrm{O}_{4}$ and $\mathrm{MR}-\mathrm{Fe}_{3} \mathrm{O}_{4}$ are about 27.3, 13.8 and $9.8 \mathrm{~nm}$, respectively. These results agree with the TEM data. In the patterns of $\mathrm{C}-\mathrm{Fe}_{3} \mathrm{O}_{4}$ and $\mathrm{C}-\mathrm{Fe}_{3} \mathrm{O}_{4} @ \mathrm{C}$, a small peak appearing at about $37.1^{\circ}$ of $2 \theta$ is attributed to crystal plane (222). Actually, the other patterns also have this peak. But the peak intensity is very weak. It is possible that $\mathrm{C}-\mathrm{Fe}_{3} \mathrm{O}_{4}$ has relatively big size and high crystallinity. No obvious new diffraction peak appears in the XRD pattern of $\mathrm{Fe}_{3} \mathrm{O}_{4} @ \mathrm{C}$ composites, demonstrating the amorphous structure of the carbon shell. The FTIR spectra of $\mathrm{Fe}_{3} \mathrm{O}_{4}$ and $\mathrm{Fe}_{3} \mathrm{O}_{4} @ \mathrm{C}$ composites are shown in figure 4 . The wide strong peak in the range of $55-580 \mathrm{~cm}^{-1}$ is contributed to $\mathrm{Fe}-\mathrm{O}$ stretching vibration of $\mathrm{Fe}_{3} \mathrm{O}_{4}$ [23-26]. It is well known that 

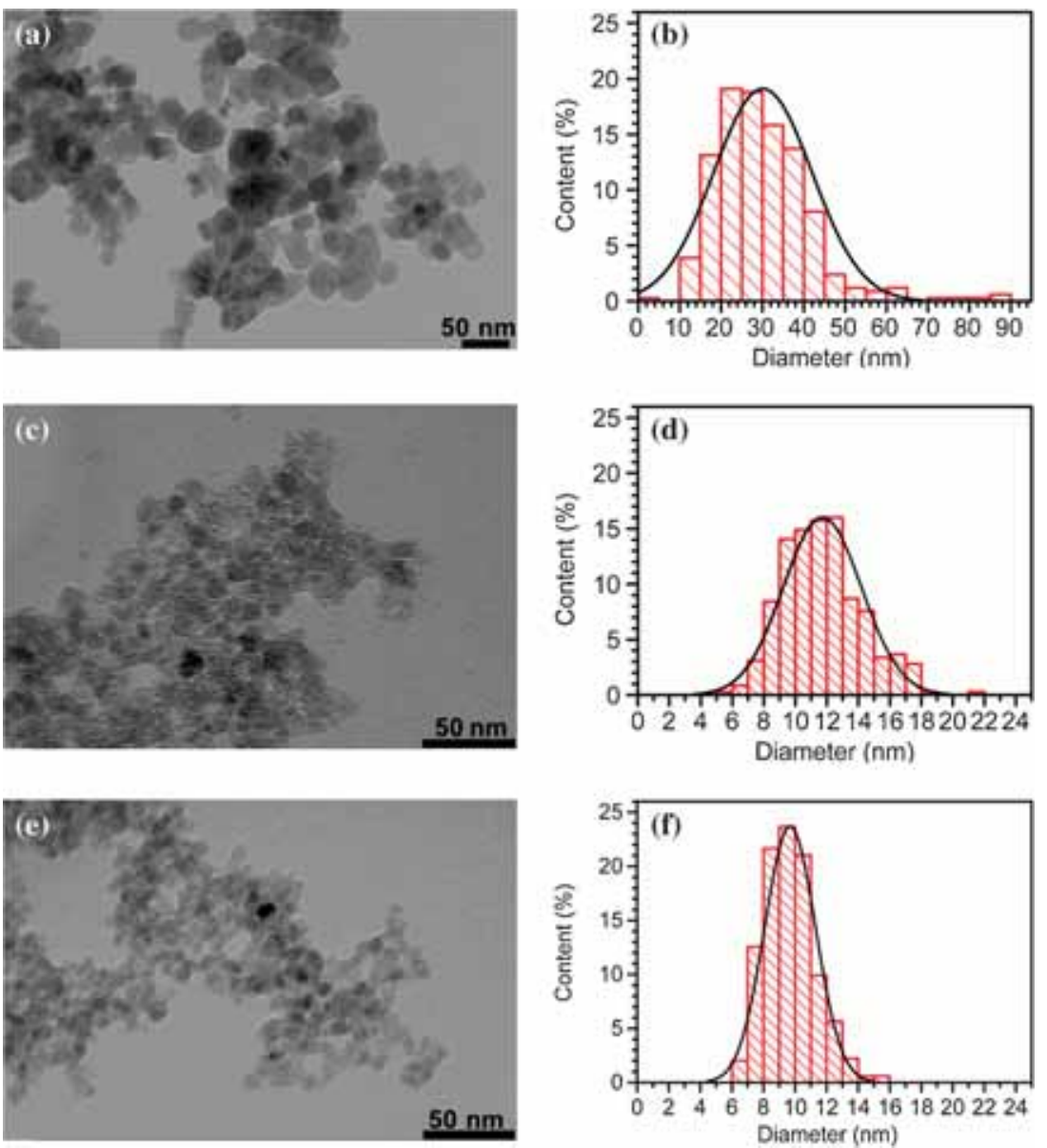

Figure 1. TEM images and statistical size-distribution histograms, respectively, of (a, b) $\mathrm{C}-\mathrm{Fe}_{3} \mathrm{O}_{4},(\mathbf{c}, \mathbf{d}) \mathrm{TA}-\mathrm{Fe}_{3} \mathrm{O}_{4}$ and (e, f) $\mathrm{MR}-\mathrm{Fe}_{3} \mathrm{O}_{4}$.
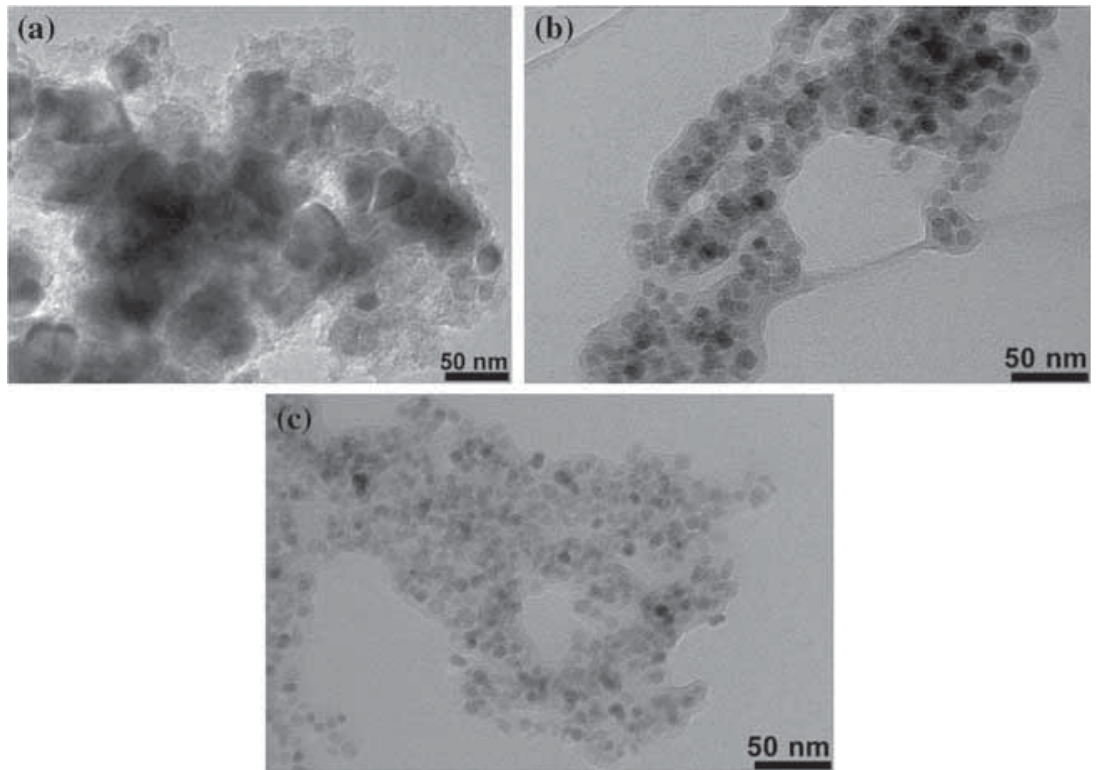

Figure 2. TEM images of (a) $\mathrm{C}-\mathrm{Fe}_{3} \mathrm{O}_{4} @ \mathrm{C}$, (b) $\mathrm{TA}-\mathrm{Fe}_{3} \mathrm{O}_{4} @ \mathrm{C}$ and (c) MR$\mathrm{Fe}_{3} \mathrm{O}_{4} @ \mathrm{C}$. 


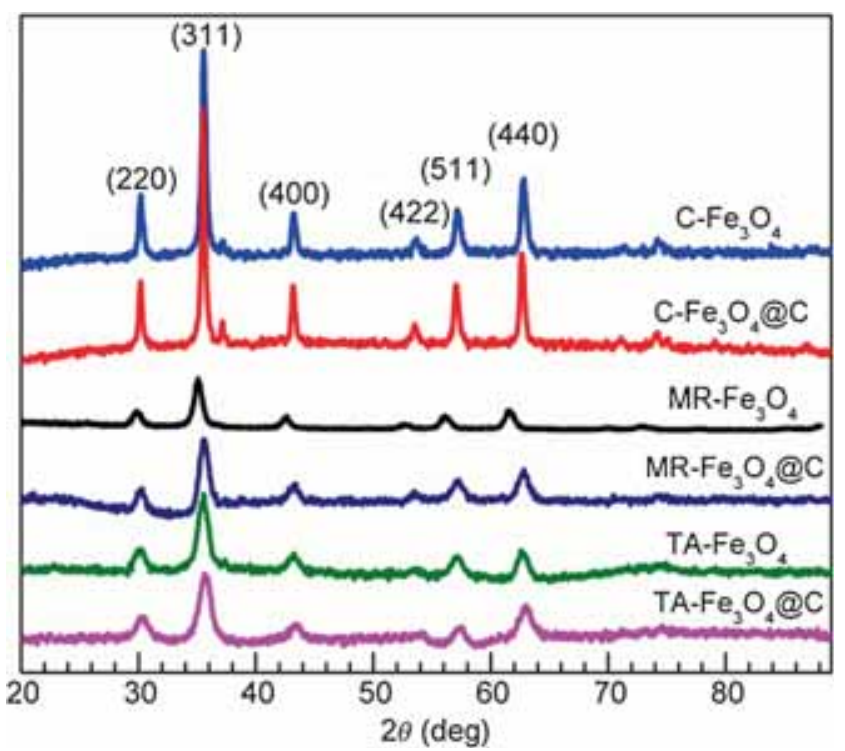

Figure 3. XRD patterns of $\mathrm{Fe}_{3} \mathrm{O}_{4}$ and $\mathrm{Fe}_{3} \mathrm{O}_{4} @ \mathrm{C}$ composites.

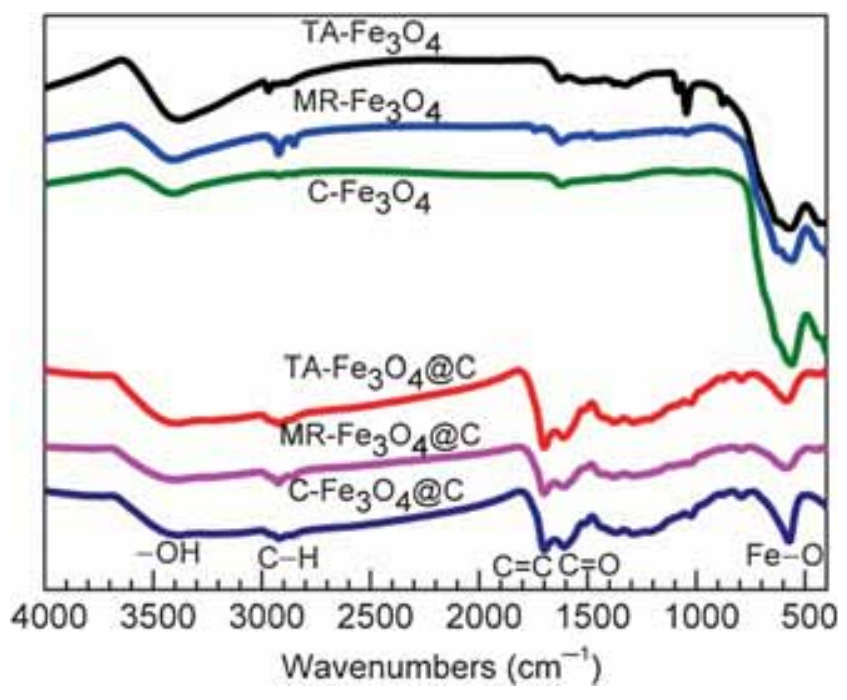

Figure 4. FTIR spectra of $\mathrm{Fe}_{3} \mathrm{O}_{4} \mathrm{NPs}$ and $\mathrm{Fe}_{3} \mathrm{O}_{4} @ \mathrm{C}$ composites.

the absorption band of nanomaterial becomes wide with the decrease of its size. This is possibly the main reason for the wide peak shape. The shape difference of $\mathrm{Fe}-\mathrm{O}$ stretching vibration peak between $\mathrm{Fe}_{3} \mathrm{O}_{4}$ and $\mathrm{Fe}_{3} \mathrm{O}_{4} @ \mathrm{C}$ may originate from the carbon encapsulation of $\mathrm{Fe}_{3} \mathrm{O}_{4}$. The peaks at 1600 and $1696 \mathrm{~cm}^{-1}$ are characteristics of $\mathrm{C}=\mathrm{O}$ and $\mathrm{C}=\mathrm{C}$ vibrations [27]. The weak peak at $3377 \mathrm{~cm}^{-1}$ belongs to vibration of $-\mathrm{OH}$ group [28]. The broad region from 2780 to $3000 \mathrm{~cm}^{-1}$ is assigned to $\mathrm{C}-\mathrm{H}$ vibration. The existence of $\mathrm{C}-\mathrm{H}, \mathrm{C}=\mathrm{O}$ and $\mathrm{C}=\mathrm{C}$ clearly demonstrates the existence of carbon. Figure 5 displays the XPS spectra of $\mathrm{Fe}_{3} \mathrm{O}_{4} @ \mathrm{C}$ composites. The two main peaks for $\mathrm{Fe}_{3} \mathrm{O}_{4} @ \mathrm{C}$ composites are located at about 285 and $532.7 \mathrm{eV}$ which correspond to $\mathrm{C} 1 \mathrm{~s}$ and $\mathrm{O} 1 \mathrm{~s}$ peaks, respectively. The carbon contents of both $\mathrm{Fe}_{3} \mathrm{O}_{4} @ \mathrm{C}$ composites are beyond 70\%. The enlarged $\mathrm{Fe} 2 \mathrm{p}$
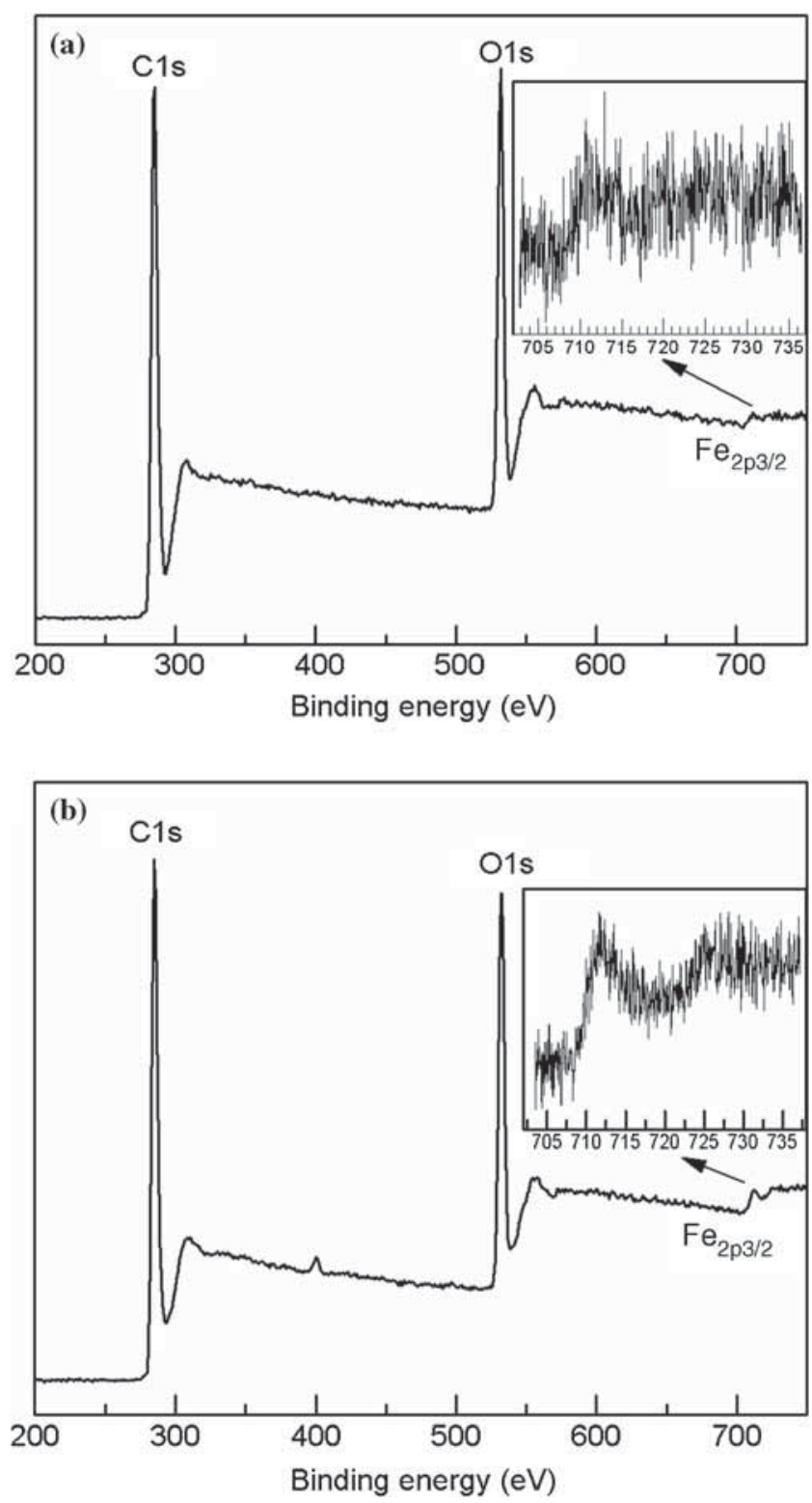

Figure 5. XPS spectra of (a) $\mathrm{TA}-\mathrm{Fe}_{3} \mathrm{O}_{4} @ \mathrm{C}$ and (b) MR$\mathrm{Fe}_{3} \mathrm{O}_{4} @ \mathrm{C}$.

peaks $\left(\mathrm{Fe}_{2 \mathrm{p} 1 / 2}\right.$ and $\left.\mathrm{Fe}_{2 \mathrm{p} 3 / 2}\right)$ for both composites were interpolated in figure 5. The results demonstrate that $\mathrm{Fe}_{3} \mathrm{O}_{4} \mathrm{NPs}$ have been encapsulated by a carbon layer. Figure 6 a presents the magnetization hysteresis loops of $\mathrm{Fe}_{3} \mathrm{O}_{4}$ and $\mathrm{Fe}_{3} \mathrm{O}_{4} @ \mathrm{C}$ composites at room temperature. All of the samples possess superparamagnetic property. The remnant magnetization values of $\mathrm{C}-\mathrm{Fe}_{3} \mathrm{O}_{4}, \mathrm{TA}-\mathrm{Fe}_{3} \mathrm{O}_{4}$ and $\mathrm{MR}-\mathrm{Fe}_{3} \mathrm{O}_{4}$ are only $0.55,0.13$ and $0.12 \mathrm{emu} \mathrm{g}^{-1}$, respectively. The saturation magnetization values $\left(M_{\mathrm{s}}\right)$ of $\mathrm{C}-\mathrm{Fe}_{3} \mathrm{O}_{4}, \mathrm{MR}-\mathrm{Fe}_{3} \mathrm{O}_{4}$ and TA- $\mathrm{Fe}_{3} \mathrm{O}_{4}$ are 67.3, 64.0 and $56.1 \mathrm{emu} \mathrm{g}^{-1}$, respectively. The corresponding values of C- $\mathrm{Fe}_{3} \mathrm{O}_{4} @ \mathrm{C}, \mathrm{MR}-\mathrm{Fe}_{3} \mathrm{O}_{4} @ \mathrm{C}$ and TA- $\mathrm{Fe}_{3} \mathrm{O}_{4} @ \mathrm{C}$ composites are respectively $45.5,19.0$ and $16.5 \mathrm{emu} \mathrm{g}^{-1}$. As we know, the ferromagnetic response of the superparamagnetic particle decreases with the reduction of its size. Of course, the ferromagnetic response is also related to its crystallinity. 

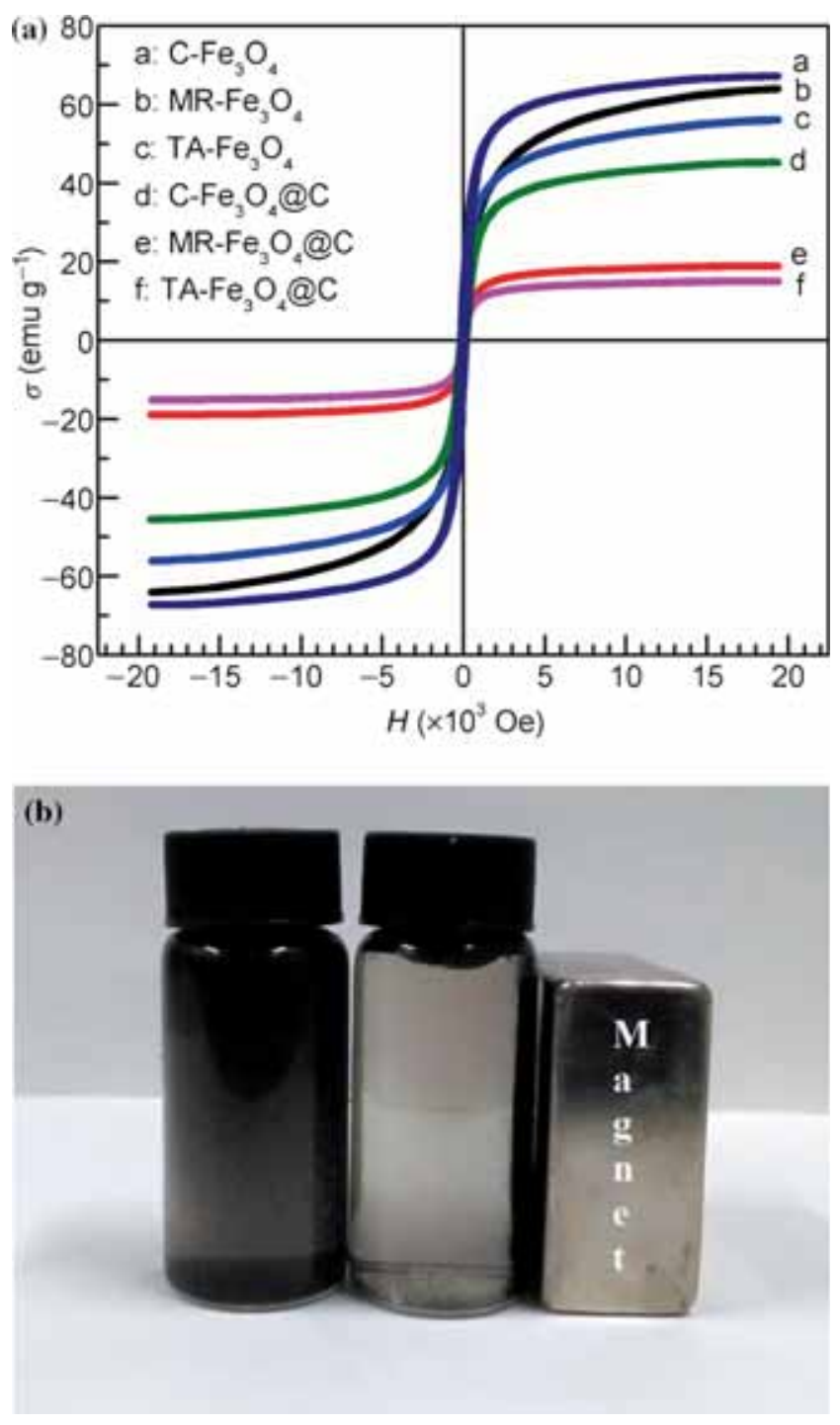

Figure 6. (a) Magnetic hysteresis loops of $\mathrm{Fe}_{3} \mathrm{O}_{4}$ and $\mathrm{Fe}_{3} \mathrm{O}_{4} @ \mathrm{C}$ composites. (b) Photograph of an aqueous suspension of MR$\mathrm{Fe}_{3} \mathrm{O}_{4} @ \mathrm{C}$ and its separation by an external magnet.

The relatively large $M_{\mathrm{s}}$ values of $\mathrm{C}-\mathrm{Fe}_{3} \mathrm{O}_{4}$ and $\mathrm{C}-\mathrm{Fe}_{3} \mathrm{O}_{4} @ \mathrm{C}$ composite are mainly attributed to the big size and high crystallinity of $\mathrm{C}-\mathrm{Fe}_{3} \mathrm{O}_{4}$ NPs. That the MR- $\mathrm{Fe}_{3} \mathrm{O}_{4}$ NPs have relatively stronger $M_{\mathrm{s}}$ than that of the TA- $\mathrm{Fe}_{3} \mathrm{O}_{4} \mathrm{NPs}$ may be related to crystallinity and defect of NPs [29,30]. It has been reported that $16.3 \mathrm{emu} \mathrm{g}^{-1}$ of $M_{\mathrm{S}}$ is enough for magnetic separation via alternative magnetic field [31]. Figure $6 \mathrm{~b}$ shows a photograph of an aqueous suspension of $\mathrm{MR}-\mathrm{Fe}_{3} \mathrm{O}_{4} @ \mathrm{C}$ (left) and its separation by an external magnet (right). Its recovery $\eta$ exceeds $99.1 \%$. The magnetic properties of $\mathrm{Fe}_{3} \mathrm{O}_{4} @ \mathrm{C}$ make them easily separated from water, which exhibits its potential as a magnetic adsorbent.

$\mathrm{RhB}$ was used as a model compound to evaluate the adsorption property of the $\mathrm{Fe}_{3} \mathrm{O}_{4} @ \mathrm{C}$ composites. Firstly, the time required to achieve adsorption equilibrium was determined, which was carried at $20^{\circ} \mathrm{C}$ and $\mathrm{pH}$ value of 3 . The absorption capacities of the $\mathrm{Fe}_{3} \mathrm{O}_{4} @ \mathrm{C}$ composites rise

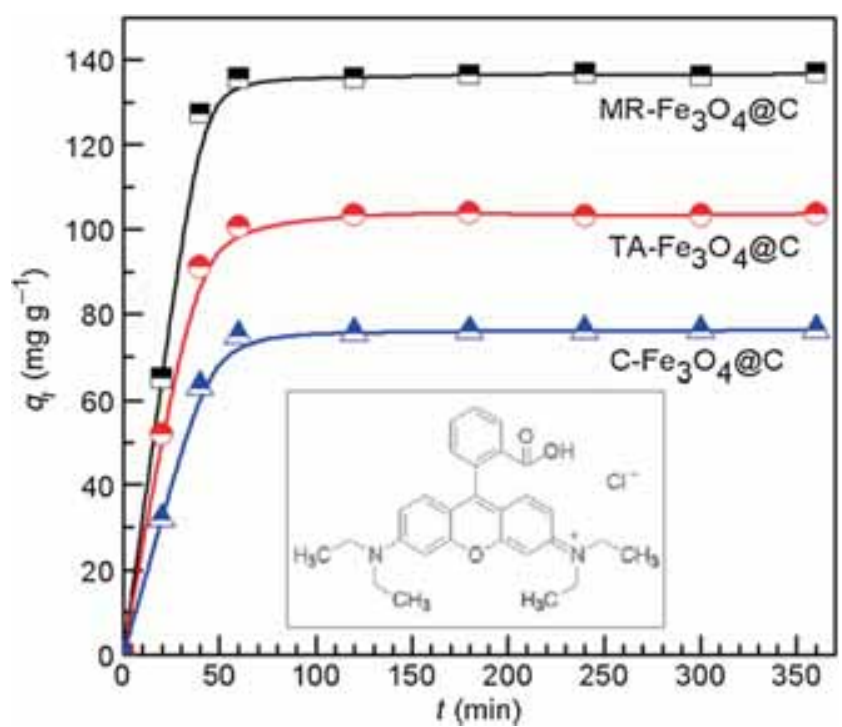

Figure 7. $\mathrm{RhB}$ isothermal absorption curves of $\mathrm{Fe}_{3} \mathrm{O}_{4} @ \mathrm{C}$ composites.

rapidly and reach equilibrium values after about $60 \mathrm{~min}$. $\mathrm{RhB}$ is a cationic dye (inset in figure 7). The electrostatic interaction between $\mathrm{Fe}_{3} \mathrm{O}_{4} @ \mathrm{C}$ composites and $\mathrm{RhB}$ is one of the important factors affecting the adsorption ability [23,32]. Furthermore, adsorption ability will also be strengthened due to hydrogen bonds between hydroxyl groups and carbonyl groups $[33,34]$. The saturation capacity of $\mathrm{MR}-\mathrm{Fe}_{3} \mathrm{O}_{4} @ \mathrm{C}$ composite exceeds $135 \mathrm{mg} \mathrm{g}^{-1}$, whereas the values of C$\mathrm{Fe}_{3} \mathrm{O}_{4} @ \mathrm{C}$ and TA- $\mathrm{Fe}_{3} \mathrm{O}_{4} @ \mathrm{C}$ composites are only about 76 and $100 \mathrm{mg} \mathrm{g}^{-1}$, respectively. Absorbing properties of only MR- $\mathrm{Fe}_{3} \mathrm{O}_{4} @ \mathrm{C}$ and TA- $\mathrm{Fe}_{3} \mathrm{O}_{4} @ \mathrm{C}$ were compared in the following discussion due to the relatively weak absorption capacity of $\mathrm{C}-\mathrm{Fe}_{3} \mathrm{O}_{4} @ \mathrm{C}$ composite. Figure 8a shows the effect of temperature on the saturation absorption of the composites ( $\mathrm{pH}$ of 3 and $60 \mathrm{~min}$ of contact time). It is evident that the adsorption capacities increase with the increase of absorption temperature and reach the maximum values at $60^{\circ} \mathrm{C}\left(149\right.$ and $177 \mathrm{mg} \mathrm{g}^{-1}$ for TA- $\mathrm{Fe}_{3} \mathrm{O}_{4} @ \mathrm{C}$ and MR$\mathrm{Fe}_{3} \mathrm{O}_{4} @ \mathrm{C}$, respectively). This may be attributed to the generation of some new active sites on the surface of absorption materials due to bond rupture [35]. In addition the higher collision probability between $\mathrm{RhB}$ and adsorbent could also enhance the adsorption capacity. The corresponding absorption capacities drop to 141 and $170 \mathrm{mg} \mathrm{g}^{-1}$ at $70^{\circ} \mathrm{C}$. Figure $8 \mathrm{~b}$ displays the effect of initial $\mathrm{pH}$ on $\mathrm{RhB}$ adsorption capacity at $20^{\circ} \mathrm{C}$. When the $\mathrm{pH}$ value increases from 3 to 9 , the adsorption capacities of TA- $\mathrm{Fe}_{3} \mathrm{O}_{4} @ \mathrm{C}$ and MR$\mathrm{Fe}_{3} \mathrm{O}_{4} @ \mathrm{C}$ respectively increase from 104 and $135 \mathrm{mg} \mathrm{g}^{-1}$ to 122 and $155 \mathrm{mg} \mathrm{g}^{-1}$. In the range of $9-11$, the adsorption capacities for both adsorbents decreased slightly. At lower $\mathrm{pH}$, the adsorption of $\mathrm{H}^{+}$on the surface of adsorbent makes it positively charged. The increase of $\mathrm{pH}$ value leads to the negatively charged sites. When the adsorbent surface becomes negatively charged, the adsorption capacity reaches the maximum due to the strong electrostatic attraction between 

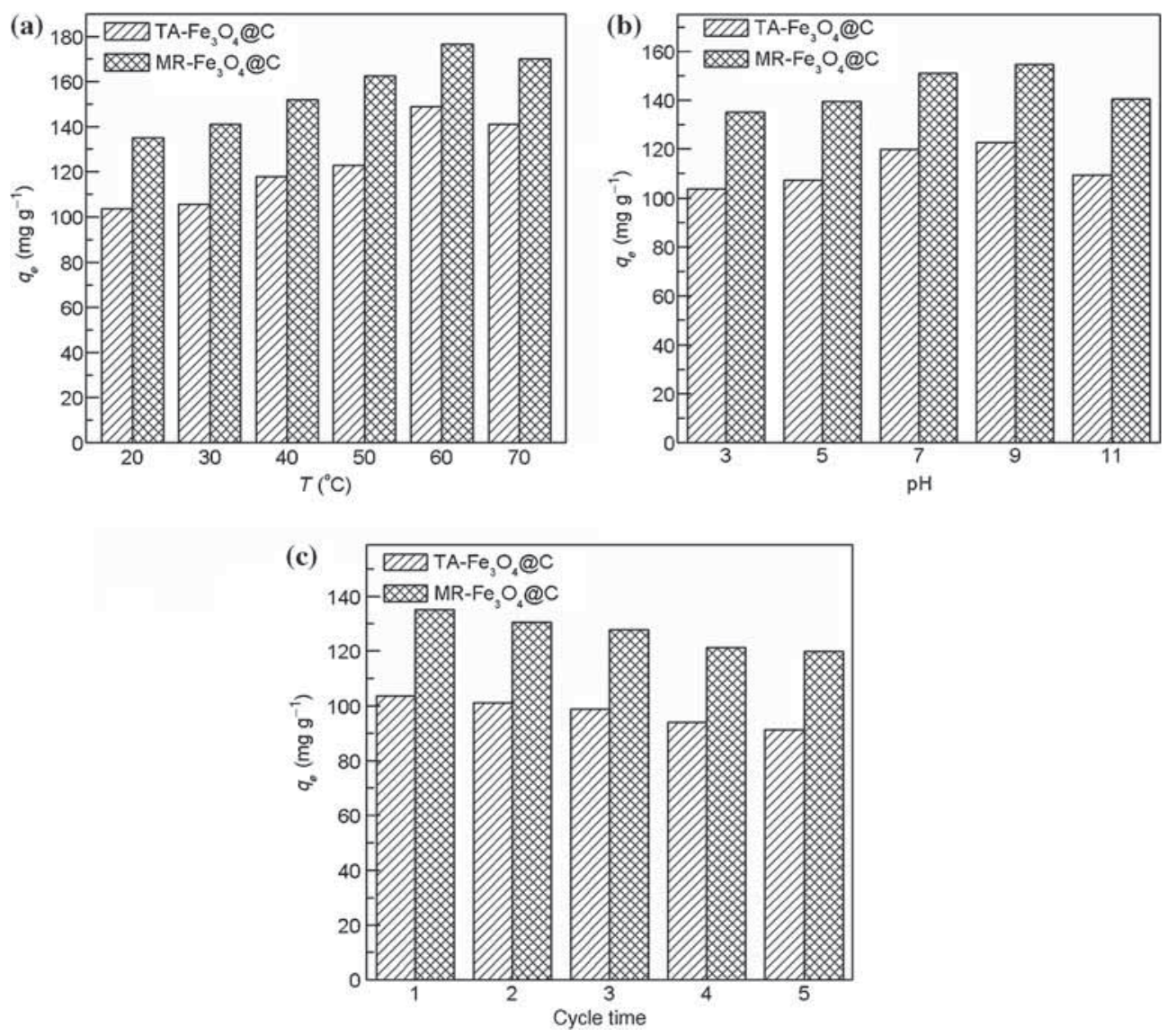

Figure 8. Effect of (a) temperature, (b) $\mathrm{pH}$ and (c) cycle time on absorption capacity of $\mathrm{Fe}_{3} \mathrm{O}_{4} @ \mathrm{C}$ composites.

the adsorbent and $\mathrm{RhB}$ [36]. At much higher $\mathrm{pH}$, the ion form of $\mathrm{RhB}$ changes from monomeric form to zwitterionic form, which leads to RhB aggregate [37]. The steric effect will hinder the absorption of $\mathrm{RhB}$ molecule on adsorbent. After adsorption, the adsorbents were simply regenerated by washing with deionized water. As seen in figure $8 \mathrm{c}$, the adsorption capacities of TA- $\mathrm{Fe}_{3} \mathrm{O}_{4} @ \mathrm{C}$ and $\mathrm{MR}-\mathrm{Fe}_{3} \mathrm{O}_{4} @ \mathrm{C}$ respectively decrease from 104 and 135 to 92 and $120 \mathrm{mg}$ $\mathrm{g}^{-1}$ after four cycles. The $\mathrm{Fe}_{3} \mathrm{O}_{4} @ \mathrm{C}$ composites still have excellent adsorption ability. The results indicate that both TA- $\mathrm{Fe}_{3} \mathrm{O}_{4} @ \mathrm{C}$ and $\mathrm{MR}-\mathrm{Fe}_{3} \mathrm{O}_{4} @ \mathrm{C}$ could be reused, especially for $\mathrm{MR}-\mathrm{Fe}_{3} \mathrm{O}_{4} @ \mathrm{C}$ composite

\section{Conclusions}

$\mathrm{Fe}_{3} \mathrm{O}_{4} @ \mathrm{C}$ composites were prepared by hydrothermal method using three kinds of $\mathrm{Fe}_{3} \mathrm{O}_{4} \mathrm{NPs}$ as core: one from traditional coprecipitation, one from a microreactor and commercial $\mathrm{Fe}_{3} \mathrm{O}_{4}$. The $\mathrm{Fe}_{3} \mathrm{O}_{4}$ NPs from the microreactor have the smallest average size and size distribution among them. The $\mathrm{Fe}_{3} \mathrm{O}_{4} @ \mathrm{C}$ composite using microreactor-prepared $\mathrm{Fe}_{3} \mathrm{O}_{4}$ NPs with 19.0 emu $\mathrm{g}^{-1}$ of saturated magnetization could be easily separated from water by a magnet. Its $\mathrm{RhB}$ saturation absorption capacity at relatively optimal condition exceeds $177 \mathrm{mg} \mathrm{g}^{-1}$ which is much larger than that of the other two composites. This $\mathrm{Fe}_{3} \mathrm{O}_{4} @ \mathrm{C}$ composite also has excellent reusability.

\section{Acknowledgements}

This work was supported by the Fundamental Research Funds for the Central Universities of China (JD1406) and the National Natural Science Foundation of China (21174011, U1462102).

\section{References}

[1] Zhang F, Liu Y J, Xiao X C, Cai X Y, Li H and Wang Y D 2012 Mater. Technol. 27196

[2] Zhang F, Liu Y J, Liu Q H, Li Q, Li H, Cai X Y and Wang Y D 2013 Mater. Technol. 28310

[3] Mahmoodi N M and Masrouri O 2015 J. Solution Chem. 441568

[4] Farahani Z H, Mahmoodi N M and Monfared H H 2015 Fiber. Polym. 161035

[5] Zhang S X, Niu H Y, Hu Z J, Cai Y Q and Shi Y L 2010 J. Chromatogr. A 12174757

[6] Zhang Y X, Xu S C, Luo Y Y, Pan S S, Ding H L and Li G H 2011 J. Mater. Chem. 213664

[7] Fan W, Gao W, Zhang C, Tjiu W W, Pan J S and Liu T X 2012 J. Mater. Chem. 2225108 
[8] Liang L, Zhu Q C, Wang T B, Wang F X, Ma J, Jing L Q and Sun J M 2014 Micropor. Mesopor. Mater. 197221

[9] Shi S, Fan Y W and Huang Y M 2013 Ind. Eng. Chem. Res. 522604

[10] Zhang C, Mo Z L, Zhang P, Feng C and Guo R B 2013 Mater. Lett. 106107

[11] Zhao L Q, Chang X L, Liao R, Zhang X L, Xie J R, Yu B W, Wu R H, Wang R J and Yang S T 2014 Mater. Lett. 135154

[12] Cai W and Wan J Q 2007 J. Colloid. Interf. Sci. 305366

[13] Wang J, Chen Q W, Zeng C and Hou B Y 2004 Adv. Mater. 16137

[14] Tang N J, Zhong W, Jiang H Y, Wu X L, Liu W and Du Y W 2004 J. Magn. Magn. Mater. 28292

[15] Chen M J, Shen H, Li X and Liu H F 2014 Appl. Surf. Sci. 307306

[16] Meng H N, Zhang Z Z, Zhao F X, Qiu T and Yang J D 2013 Appl. Surf. Sci. 280679

[17] Karaoglu E, Baykal A, Deligoz H, Senel M, Sozeri H and Toprak M S 2011 J. Alloys Compd. 5098460

[18] Tao K, Dou H J and Sun K 2008 Colloid. Surf. A 320115

[19] Jahnisch K, Hessel V, Lowe H and Baerns M 2004 Angew. Chem. Int. Ed. Engl. 43406

[20] Song Y J, Hormes J and Kumar C S S R 2008 Small 4698

[21] Jensen K F 2001 Chem. Eng. Sci. 56293

[22] Yao X J, Zhang Y, Du L Y, Liu J H and Yao J F 2015 Renew. Sust. Energ. Rev. 47519

[23] Zhang Z Y and Kong J L 2011 J. Hazard. Mater. 193325
[24] Socrates G 2001 Infrared and Raman characteristic group frequencies: tables and charts (Chichester: Wiley)

[25] Silverstein R M, Webster F X and Kiemle D J 1997 Spectrometric identification of organic compounds (New York: Wiley)

[26] Cornell R M and Schwertmann U 2003 The iron oxides: structure, properties, reactions occurrences and uses (Wiley: Weinheim)

[27] Bai L, Mei B, Guo Q Z, Shi Z G and Feng Y Q 2010 J. Chromatogr. A 12177331

[28] Pol V G, Daemen L L, Vogel S and Chertkov G 2010 Ind. Eng. Chem. Res. 49920

[29] Huang J, Chen W M, Zhao W, Li Y Q, Li X G and Chen C P 2009 J. Phys. Chem. C 11312067

[30] Tan Y W, Zhuang Z B, Peng Q and Li Y D 2008 Chem. Mater. 205029

[31] Zhao W, Yang R J, Qian T T, Hua X, Zhang W B and Katiyo W 2013 Int. J. Mol. Sci. 1412073

[32] Iram M, Gu C, Guan Y P, Ishfaq A and Liu H Z 2010 J. Hazard. Mater. 1811039

[33] Konicki W, Cendrowski K, Bazarko G and Mijowska E 2015 Chem. Eng. Res. Des. 94242

[34] Ahmad R and Kumar R 2010 J. Environ. Manage. 911032

[35] Aksu Z and Kabasakal E 2004 Sep. Purif. Technol. 35223

[36] Ai L H, Huang H Y, Chen Z L, Wei X and Jiang J 2010 Chem. Eng. J. 156243

[37] Gad H M H and El-Sayed A A 2009 J. Hazard. Mater. 1681070 